\title{
脳を創る
}

\section{一第 2 回 脳の構成原理と生体情報—}

\author{
松本 元, 市川道 教 \\ 理化学研究所 脳科学総合研究センター \\ ブレインウェイ (脳道) グループ*
}

\section{序一脳は思えばその事を成すアルゴリズムを 自動獲得するシステム}

第 1 回に引きつづき「脳とはどんなコンピュータ か」について考光る。第 1 回では, 脳の目的が, “情 報を選択し，その情報の処理の仕方（アルゴリズム） を獲得すること”，この為の情報原理（脳の情報処理 システムとしての特徴を貫く原理）がメモリーベース アーキテクチャであること，を述べた。すなわち，脳 は思えばその事を成す為のアルゴリズムが脸に獲得さ れるシステムである。この事は，例えば，われわれが 言語野を獲得したのは，われわれが人とコミュニケー トしたいという思いに依っている，ということであ る. 強く思えば, その事を成す為のアルゴリズムが獲 得され, それが脳の構造とそこでの活動として表現さ れるからである，従って，この立場（われわれの意味 での「脳を創る」と言う立場）から，何故人は言語を 獲得しコミュニケートできるのかを理解する為のアプ ローチとしての第一歩は, 人が何故人との間のコミュ ニケートを強く望むかを知ることである，言語は人同 士のコミュニケーションの為の手段であり, 人が生き てゆく上で人とのコミュニケーションが本質的に重要 であり，この事が無ければ人は生きられない存在であ ればこそ, 人の脳は言語野を広い領域に展開している のである。これに対し，「脳を知る」立場からの脳研 究は, 言語野の構造やそこでの活動がどの様に表現さ れているのかの解明が, その目的であろう（第 1 回図 1 参照).

脳の目的が, アルゴリズムの自動獲得であり, 出力 することはその為の手段である (図 3 参照) というこ とを, コンピュータとの対比において第 1 回で述べ た.コンピュータの目的は, 入力情報を人が与えたプ ログラム（情報処理の仕方としてのアルゴリズム表現

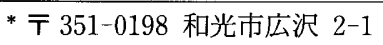

の一形態）に従って, 出力することである. 従って, 出力が目的のコンピュータの性能評価は, 出力される 事柄に対し行われるべきものであり, 実際, コンピュ 一夕の性能は, 主としてこの様な視点でなされてい る。これに対し, 脳の目的が, アルゴリズム獲得への プロセスであるということであるなら，人(脳) の評 価は脳がどれだけの出力（成果）を成したか, に対し てではなく，脳のアルゴリズム獲得へのプロセスに対 してなされるべきである，すなわち，人（脳）の目的 は，つまり頂点に到達することではなく，高きに向か って成長してゆく姿勢（プロセス）にあるのであっ て, 人を出来高（どの位の能力を獲得したか）で評価 することは，脳の本来のあり方とそぐわず，かえって 人（脳）を苦しめ脳の発達を阻害する．この立場か ら, 山を登る人が,「何故山に登るのか」と問われた とき，「そこに山があるから」と答えるのは, 合脳的 (脳のあり方にそぐわしい) と言える，それは，自分 でどの山に登るかを選定し山を登って行く過程を最も 大切に考え, 時及小高い丘に立ち止まって, 登ってき た道を振り返り, 自分が確かに登っていることを確認 することであり，決して頂点に立つことを目的とはし ていない. 勿論, この様にしてプロセスを大事にする ことで, 結果として頂点に立つ。いらそのときの出 来高（出力）が良くても, その出来高（出力）を得る ことが目的で，成長することがそれに伴わないという のでは脳の本来の目的とはそぐわない.

本稿第 2 回“脳を創る”では, この脳の目的を遂行 する為の脳の構成原理が, 先読みと階層構造性にある ことを述べる，さらに，この構成原理は，遺伝情報を 含めた生体情報に共通した原理であることを述べる. 従って，人が人の集まりとしての社会のあり様を考え る場合，生体情報を貫く原理と同型，(homologous） の社会構成を創るべきである。この立場から人文・社 会科学や宗教のあり方に対する提言は, 本連載の中で 詳しく行うことはしないが, 現在の資本主義社会の人 
や組織に対する “出来高”を評価の主対象にする行き 方は，人を中心に据えた社会システムのあり様ではな いことは明言できよう。

\section{1. 脳とはどんなコンピュータか： 脳の情報原理と構成原理}

\section{1 脳の情報原理}

脳の情報原理がメモリーベースアーキテクチャであ ること，これに対して，コンピュータの情報原理はプ ロセッサベースのアーキテクチャであること，さらに 脳とコンピュータのこれらの原理の違いに基づく情報 処理システムとしての特徵の比較について, 第 1 回で 概括した (第 1 回参照). 但し, 序で述べた様に脳と コンピュータの目的が違うので, それぞれの特徴を比 較検討はしたが，出来高評価的な性能此較はしなかっ た。

\section{2 脳の構成原理}

脳を具体的に構成してゆく為の原理について，ここ で考える.脳の構成原理が先読みと階層構造性にある ことを述べる。

\subsection{1 先 読み}

脳は，情報を選択しその情報の処理の仕方（アルゴ リズム）を獲得することを目的とするシステムであ り, 脳からの出力はアルゴリズム獲得の手段である (図 3)。すなわち，アルゴリズムの獲得のアルゴリズ

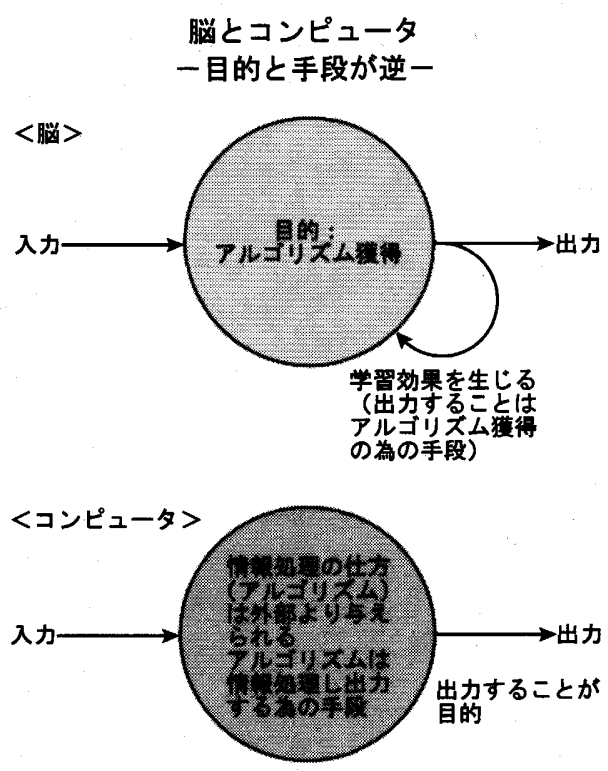

図 3 脳とコンピュータの情報処理システムとしての それぞれの目的
ムを学習アルゴリズムというと, 学習アルゴリズムは 出力依存性である，学習アルゴリズムが出力依存性で あるということは, 出力時に入力を得ている情報（出 力の直接の原因となった入力情報）あるいは出力時よ り以前に入力を得ていた情報との関連が強化・減弱さ れることを意味する，とくに，後者の場合，時系列情 報の連合学習の “先読み”が行える形態となることに 注意しょう。それは, 出力を得たとき, それ以前に得 た入力情報とこの出力との関連が強化されたとする と, この学習成立以降ではこの入力情報を得たとき, 次にこのときの出力の先読みがなされるからである. こうして, 脳は, 過去の学習をもとにメモリーベース アーキテクチャを構成し, この構成から将来を先読み し, 現在に対応するシステムと言える. 脳での学習ア ルゴリズムが出力依存性であることから, 学習によっ て頻繁にアルゴリズムの変更を必要としない場合に は, 出力の頻度を大幅に減少させることが予想され る.この事は, 例えば小脳のプルキンエ細胞での登上 線維経由の入力から生じる複雑スパイクが, 苔状線維 経由入力から生じる単純スパイクに比べてその頻度が 何故極めて低いが解釈を与えるだろう。また，脳 での学習が出力依存性であることが, 脳の階層構造化 と密接に関係する (1.2.2 節を参照).

脳の情報原理と構成原理の背後にある非線形非平衡 システムとしての特徵は, 大域から局所にわたって同 型の構造をしていると考えられる. 細胞より下位のレ ベルに関しては, 次節 1.3 で考察することにして, 神 経細胞，ニューロンネットワーク及び脳全体の各レ心゙ ルについて考察しょう：

神経細胞レベル

神経細胞の学習効果とは, 神経細胞間の情報伝達効 率の変化を生じさせることであり，その効果がシナプ スの情報伝達の結合変化として表現される, と仮定し よう.この神経細胞での時系列情報連合の出力依存性 学習アルゴリズムの提案は, 重松らによってなされて いる ${ }^{2,3)}$.ここでは, 神経細胞が入力を得たとき，そ れによって出力する・しないにかかわらず，入力情報 を得たシナプスにその痕跡を記憶として残す。その記 憶值は時間と共にある特定の緩和時間をもって減衰す る. 神経細胞が出力を得たとき, 出力端よりその同じ 神経細胞のすべてのシナプス部位に基本的にシナプス 痕跡值の残留值が調べられ, その值が閾值 $H_{1}$ より大 きいとき学習効果が生じ, シナプスの情報伝達の結合 変化が起こる. 残留置が $H_{1}$ より小さいときは, 出力 を得ても学習効果は生じない. 結合変化が強化か減弱 かは $H_{1}$ より大きい残留值が第 2 の閾値 $H_{2}\left(>H_{1}\right)$ よ 

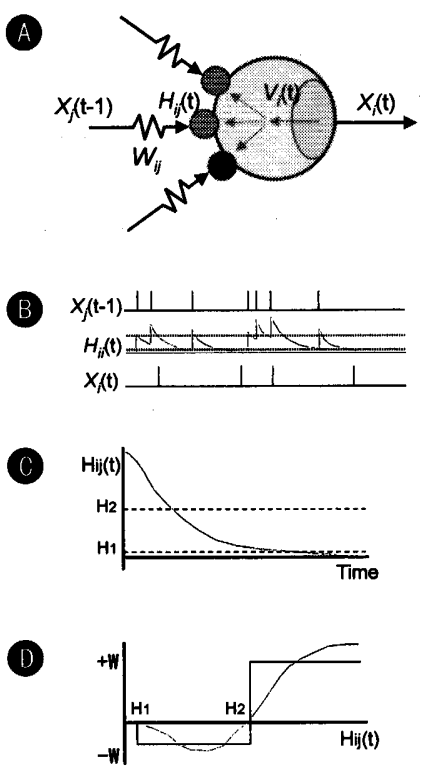

図 4 時系列情報を連合する出力依存性学習アルゴリ ズムをもつ神経素子モデル

A : パルス駆動型神経素子で各入力に履歴値を 保持し, 出力発火があると履歴值を参照し て結合係数を変更する.

$\mathrm{B}$ ：入力パルス列とその履歴值, 出力パルスの 波形。

$\mathrm{C} ：$ 履歴值の時間による減衰。

$\mathrm{D} ：$ 結合係数の変更と時間の関係.

り大きいか小さいかに依る (図 4)。この学習アルゴ リズムを検証する為に，2つの点を少なくとも明らか にする必要がある; 第 1 は, 出力情報が入力端側のす べてのシナプス部位に基本的に戻る機構は何によって 支えられているか，である，第 2 はシナプスの痕跡值 とシナプスでの情報伝達の結合変化の分子機構の解明 である，前者の機構については，神経細胞のインパル ス出力が逆行性に伝播するという最近の発見 ${ }^{4,5)}$ と強 く関係すると思われる（飯島敏夫，市川道教ら；末発 表データ). 勿論, 強い入力刺激が同期して入力する ことにより，樹状突起にインパルスが発生し，これが 樹状突起の末端まで逆行的にあるいは順行的に伝播す るときも, 同じ出力依存性学習アルゴリズムの原理が 働くと，考えられる．いずれにしても樹状突起や細胞 体が従来考えられてきた様な受動的な素子ではなく， 電圧依存性 $\mathrm{Na}$ チャンネルあるいは $\mathrm{Ca}$ チャンネルを 高密度にもつ能動的な素子であることに依っている。 後者の分子機構については, シナプスでの長期増強・ 長期抑制のメカニズムと密接に関係する.とくに, シ
ナプスでの痕跡值の分子機構は, シナプス後膜部での 細胞内 $\mathrm{Ca}^{2+}$ イオンと強く相関すると考元られ，その 詳細については現在検討中である。いずれにしても時 系列情報を連合する出力依存性学習アルゴリズムは脳 を創る上での最も基本的プロセスであり，遺伝情報が 35 億年もの年月を要して獲得した局所学習アルゴリ ズムである.

神経ネットワークレベル

神経ネットワークレベルでの出力依存性学習が神経 ネットワークの構造とそこでの活動にどの様に表現さ れているかについては, 詳しい構造学的・生理学的研 究に待たねばならない.この為の研究手法としても, 脳活動の実時間光イメージング法が一つの強力な手段 となりうる ${ }^{6)}$. 実時間光イメージング法により, 図 5 にみる様に，空間・時間分解能を極めて高く（平面的 には数 $\mu \mathrm{m}$ の空間分解能で, $0.6 \mathrm{msec}$ 程度の時間分 解能で）脳の集合的膜電位変化を計測できるので, 神 経ネットワークの機能的構造分析が行える7).さら に，この手法を改良し，無麻酔下で行動する動物の脳 に対し，慢性実験が行えるようにする努力がつづけら れている(飯島敏夫ら)。また，この様な実験では， マルチ電極の性能向上も極めて重要な技術開発課題で ある.これらの実験技術の進步によって, 神経ネット ワークレベルの学習を支えるニューラルネット構造 と，そこでの活動の表現が明らかにされる．上述した 様に, 小脳プルキンエ細胞での登上線維経由入力から 生じる複雑スパイクが, 出力依存性学習アルゴリズム の表現となっている可能性がある。また, 強化学習も 同じ立場からモデル化できる.

脳レベル

脳が出力するに至る程の強い入力情報を得たとき， この入力情報, 及び脳がそれ以前に得た情報のうち, 上記細胞のレベルでの痕跡值に相当するものに従っ て, 以前の情報とを連合して記憶を形成する。ここ で, 脳の出力とは, 認知情報処理系からの意味概念, 運動系からの行動, 言語野からの言語及び情動系から の情動表出の 4 つのいずれか及びその組み合わさった ものである．脳での記憶形成が，脳からの出力依存的 な学習に依っていることは, 例えば, ルドーら ${ }^{8)}$ のネ ズミに対する古典的条件学習付けの情動記憶形成の実 験などからも示唆される：ルドーらは, ネズミに対し ブザー音を条件刺激とし，ブザー音を聴かせた後無条 件刺激として電気ショックを数秒して与えたときの脳 内回路を研究した。この組み合わせ刺激によって条件 学習が成立し，ネズミはこの古典的条件学習付けがな されると,ブザー音だけで恐れによる逃避行動を起こ 


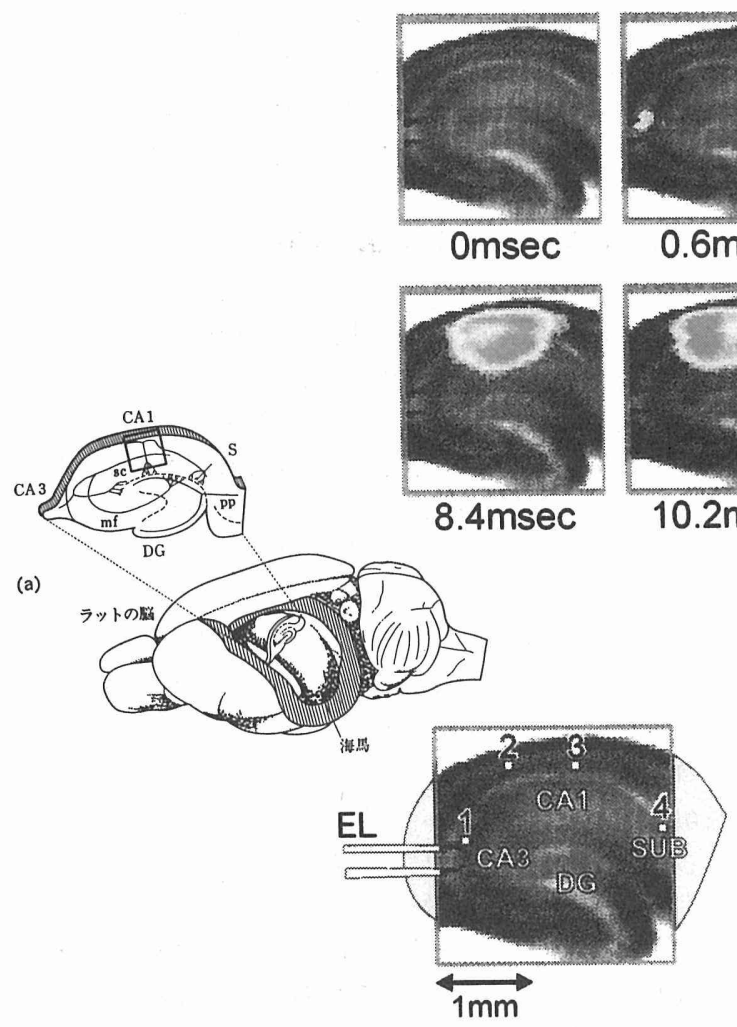

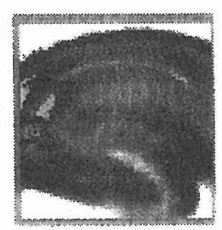

$1.8 \mathrm{msec}$

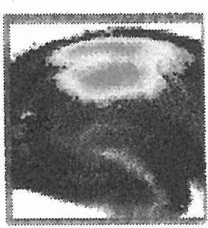

$13.8 \mathrm{msec}$

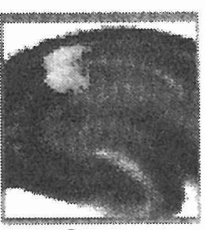

$4.2 \mathrm{msec}$

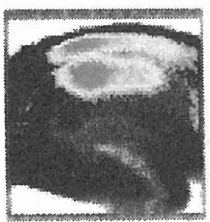

$19.8 \mathrm{msec}$

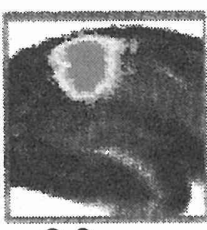

$6.0 \mathrm{msec}$

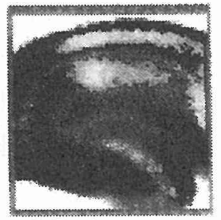

$32.4 \mathrm{msec}$

図 5 ラット海馬スライス切片に対する電気活動の実時間光イメージング

CA 3 野を電極刺激したとき，CA $3 \rightarrow$ CA $1 \rightarrow$ 海馬台への活動伝播の空間的広がりの様相が 0.6 msec の 時間分解能で計測されている (上図)。また，スライス切片の各部位（下左図の中の番号 $1 ， 2 ， 3$ 及び 4 の位置）での膜電位変化の時間経過として抽出したデータが，下右図の記録 $1,2,3$ 及び 4 である（飯島 敏夫，市川道教ら，未発表データ)。

す．この結果，血圧上昇や身体の硬直などが起こる。

この情動記憶の成立には, 聴覚系 (蝸牛 $\rightarrow$ 下丘), 内側滕状体を経て扁桃体外側核から，春髄中心灰白質 への神経情報伝達回路を介しての出力による身体の硬 直化に，また同じ扁桃体外側核からの伝達路が，外側 視床下部を経て自律神経系出力による血圧上昇の表出 に，それぞれ主たる役割を果たしていることを結論し た。さらにこの情動記憶の固定される場所は, 扁桃体 外側核であろうと結論している。すなわち, 身体の硬 直や血圧上昇として表出される情動記憶の場は, とも にこれらが表出される運動神経及び自律神経への出力 の源としての扁桃体外側部である。この事は, 脳の出 力依存性学習アルゴリズムが脳というマクロな場にお いても成り立っていることを示唆する。

\subsection{2 階層構造性}

脳が長期的に記憶を固定したとき，その記憶は生涯
消去できない。われわれが時間と共に記憶を失う（忘 れる）ように思うのは，記憶そのものが消去されてゆ くのでなく, 取り出し (retrieval) にくくなってゆく ことである。例えば，ルドーらの古典的条件学習付け の実験に扔いても,ブザー音と電気ショックによって 情動学習が成立したネズミで, ブザー音だけを与えつ づけると，身体の硬直や血圧上昇などにみられる条件 反応の大きさは時間と共に徐久に小さくなり，1〜2 ヶ月後に, 反応が観察されなくなる。これは, 通常の 脳をもつネズミ(コントロール) に対しての観察結果 である.これに対し，イボテン酸の投与や機械的な切 除によって, 大脳皮質聴覚野に損傷を与えたネズミで も，ブザー音と電気ショックの組み合わせ刺激による 情動記憶の条件反応は, まったくコントロールのネズ ミと同様に成立するのにもかかわらず，ブザー音だけ をその後与えつづけたときの条件反応の時間経過に, 
上記の緩和や消去はみられなかった。すなわち, 大脳 皮質聴覚野損傷のネズミでは, 古典的条件学習付けに よる情動記憶が一度成立すると, 生涯その記憶は緩和 も消去もできないのである, 緩和や消去の為には, こ の例では大脳皮質聴覚野を必要とする。この結果, ル ドーらは, コントロールのネズミの条件反応の消失 は, 大脳皮質聴覚野より扁桃体へのニューロンの発 芽・伸長が起こり, 情動記憶が抑制されることに依っ ていると, 解釈した. この抑制が取り除かれることが あると, 元の情動記憶が呼び出されることがある. パ ブロフも条件学習後の犬が, その後行動学習したこと を忘れたかのように振る舞ったとしても, 自発的に条 件反応が回復する事例をあげ，条件学習によって記憶 した事柄が忘れ去られてはいないことを報告してい る.

心理的な事象においても，脳が潜在下に不輝発的記 憶を階層化していることで解釉されることが, ごく普 通にみられる. 例えば, 高校 1 年生の夏に, 山岳部の

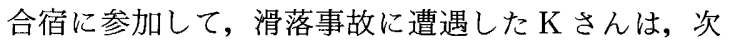
の様に語る (私信) :

$\lceil 40$ メートルザイルの 2 人パーティで, トップの私 は北壁の上方最奥の稜線直下のザラ場にさしかかりま した. 冬場の結水でゆるんだ岩の破片からなる空恐ろ しい急斜面に取り付きましたが，次の瞬間，両手足 4 個所の岩が同時にゆるみ, 私は陮落してしまいまし た。......問題は慜落の最中の私の頭の中の出来事でし た．自分が生まれてこの方経験した，ありとあらゆる （と私には思えました）出来事が，今様に申せば，誠 に美麗なグラフィックス入りで, 走馬燈のようにプレ イバックされたのです，全く忘れていたが，これはま さしく他でもない自分自身の経験以外の何物でもない と, 確信できるこのパーソナルな出来事が, たかだか 2 秒かそこらの短時間内に展開したと考えられます。 この出来事は, 個々のグラフィックス画面は明確には 思い出せないものの, 爾来 40 数年間, 忘れようにも 忘れられない出来事として, 私の脳裏に焼き付いてお ります.」

情動記憶は, 一度長期的に固定されると一生涯消去 されることがないが, 何らかの機構によって, その記 憶が時間と共に取り出しにくくなる。出力が取り出し にくくなった結果, 出力依存性学習アルゴリズムによ って, 記憶そのものは恒常的に保存される. 脳の活性 が一時的に極端に大きく上昇すると, 脳の潜在記憶が 形成の時間順序に従って, 無選択に想起されることが ある.また，その長期記憶形成したときと同じ様な状 況の入力情報を脳が得ると, それに対応した潜在記憶
が選択的に呼び出されることができる，脳は，長期的 に固定化されている記憶のアルゴリズムを活性化し出 力し, 出力するとアルゴリズムを変えるので追加学習 性を有することになり, この結果, 階層構造化すると 考えられる。

\section{3 生体情報の原理と構成原理}

生物は非線形非平衡システムである。ささらに正確に 言うなら，地球環境という非線形非平衡系の中から， それ自身が目標をもつ存在 (それ自身が目標をもつ存 在を自己をもつ存在という) が自律的に組織化された ものとして発生・分化してきたものが, 生物である. 非線形非平衡系システムの研究は, 現代物理・化学の 領野で, レーザ発振現象, 対流・層流・乱流などの流 体・気象現象, またベルーゾフ・ジャンボチンスキー 化学反応などの化学拡散反応現象など極めて詳しく研 究されてきている ${ }^{9)}$. 現在までの物理・化学分野が対 象とする非線形非平衡システムは, 物質・エネルギー に対する開放システムである，すなわち，対象とする 系が, 物質・エネルギーに関して少なくとも 2 つの異 なる環境に, 同時に接したときの系の振る舞いに関す るものである.これに対して, 従来の物理・化学が主 として対象にしてきた系は, 唯一種類の環境と物質・ エネルギーをやりとりする系である。すなわち，この 様な系は, 環境と物質・エネルギーの温度がどんなに 異なっていても所詮は平衡に至るので, 平衡系あるい は平衡に向かう非平衡系である.物質・エネルギーの 非線形非平衡系とは, 系が同時に温度の異なる 2 つ以 上の環境と物質・エネルギーのやりとりを行うので, 一方の系に平衡になろうとしても, 他方の系と平衡に なれない。この為, この系は本質的な非平衡系であ る. 非線形非平衡系では, 物質・エネルギーが温度の 高い一方の環境から系に流れ込み, 系の中をへて, 温 度の低い他方の環境に流出することで定常状態に至 る.この意味で, 非線形非平衡系は, 外部環境に対し 常に開かれている。この為, 開放系 (開いた系) と呼 ばれる。これに対し，平衡系は閉鎖系（閉じた系）で ある。物質・エネルギーに対する非線形非平衡系の研 究から, 開放系と閉鎖系の極めて著しい対比が明らか になってきた（例えば，文献 9)参照)：

1. 開放系では, 空間構造や時間構造が時間と共に 自己秩序形成される。これに対し, 閉じた系で は，時間と共に空間構造は無秩序の方向に向かう (エントロピー増大).

2. 閉じた系は線形であるので, 重ね合わせの原理 がなりたつ.すなわち，系を細分化して研究し， その各々の性質を足し合わせれば，系全体の性質 
となる.この性質の為に, 自然の中の平衡系を主 たる研究の対象にしてきた従来の科学は, 要素還 元主義や分析主義をその解明の基盤に置いてい る.これに対し, 開いた系は, 本質的に非線形で あるので, 系を要素に分けて, それぞれを詳細に 研究することは, 時として系の本質を見失いかね ない. 常にトータルな系について考える視点が必 要となる.

3. 閉じた系では時間が可逆であるのに対し, 開い た系では時間が不可逆である.この性質の為に， 閉じた系では，系の振る舞いに関する決定論的ダ イナミックスが得られると,この式の中の時間 $(t)$ の項を $(t)$ 加 $(-t)$ に置き換えても, 系の記 述は変わらない。これに対し, 開いた系では, 時 間は常に一方（過去）から他方（将来）にのみ進 み, この逆はあり得ない。すなわち, 既に一度経 過した系の状態に戻るということはできない.

4. 閉じた系では, 小さい摇動はどんなに時間が経 過しても，系に対し小さな効果でありつづける. これに対し, 開いた系では, 小さい摇動が長時間 後に, 大きな効果 (バタフライ効果と呼ぶことが ある）を引き起こす可能性があるので, 開いた系 の状態に対する長期予測は, 本質的に不可能であ る. カオス現象はこの性質を典型的に示してい る.

これらの開放系の示す性質が，神経系に如実にあら われていることは, 現在よく知られている（例えば, 文献 10) 参照)。ここでは, 生物を物質・エネルギー のみならず，物質・エネルギー以外の事柄（情報と呼 ぼう）の流れを系の中に取り込み・取り出すことを目 標としてもつ存在として捉え, 生物情報系が脳のみな らず，遺伝情報系も含めて，乙れら生物情報系の情報 原理が, 情報処理の仕方（アルゴリズム）を自動獲得 するシステムであり，構成原理が出力依存性と階層構 造性であることをみるであろう。その情報表現は, 遺 伝情報では DNA の一次元配列であり, 脳では神経ネ ットワークの三次元構造であって, 異なってはいる. しかし，それらに共通して生体情報を貫く原理・構成 原理は同型である．物質・エネルギー及び情報の非線 形非平衡系システム $\rightarrow$ 遺伝情報システム $\rightarrow$ 脳 $\rightarrow$ (社
会）という階層構造が同型であることを理解すること が，“脳を創る”立場からの脳研究にとって極めて本 質的であり,さらに人とは何かを考え, その立場から 社会をいかに構成するのが望ましいかを考えるときの 根元的立場である.

(第 3 回に続く)

\section{参 考 献}

1) Kitazawa, S., Kimura, T. and Yin, P.-G. (1998): Cerebellar complex spikes encode both destinations and errors in arm movements, Nature, Vol. 392, pp. 494-497

2) Shigematsu, Y. and Matsumoto, G. (1994): A new learning rule for temporal sequence. ICONIP '94, Seoul, pp. 1113-1116

3）重松征史 (1996)：神経回路素子と学習・記憶. 日 本物理学会編/松本 元編集, 脳・心・コンピュー 夕. (pp. 171-193) 丸善

4) Stuart, G. J. and Sakmann, B. (1994) : Active propagation of somatic action potentials into neocortical pyramidal cell dendrites, Nature, Vol. 367, pp. 69-72

5) Watanabe, S., Takagi, H., Inoue, M., Kirino, Y., Kudo, Y. and Miyakawa, H. (1998): Differential roles of two types of voltage-gated $\mathrm{Ca}^{2+}$ channels in the dendrites of cerebellar Purkinje neurons, Brain Research (in press)

6) Ichikawa, M., Iijima, T. and Matsumoto, G. (1993) : Real-time optical recording of neuronal activities in the brain. In T. Ono, L. R. Squire, M. E. Raichle, D. I. Perrett and M. Fukuda (Eds.), Brain Mechanisms of Perception and Memory. (pp. 634-648) London: Oxford University Press

7) Iijima, T., Witter, M. P., Ichikawa, M., Tominaga, T., Kajiwara, R. and Matsumoto, G. (1996) : Entorhinal-hippocampal interactions revealed by real-time imaging, Science, Vol. 272, pp. 1176-1179

8) LeDoux, J. E. (1994) : Emotion, memory and the brain, Scientific American, Vol. 270, pp. 50-57

9) Glansdorff, P. and Prigogine, I. (松本 元, 竹山 協三訳) (1976)：構造・安定性・ゆらぎーその熱 力学的理論. みすず書房

10）松本 元 $(1981,1982)$ : 神経興奮の現象と実体一 上,下. 丸善 